\title{
White Privilege and the Decolonization Work Needed in Evaluation to Support Indigenous Sovereignty and Self-Determination
}

\author{
Kate McKegg \\ The Kinnect Group
}

\begin{abstract}
This paper builds on a keynote paper presented at the 2018 Canadian Evaluation Society annual conference by Kate McKegg, a Päkehä, non-Indigenous evaluator from Aotearoa, New Zealand. Kate reflects on the concept and implications for Indigenous people of white privilege in colonized Western nations. She discusses some of the ways in which white privilege and its consequences play out in the field of evaluation, perpetuating colonial sentiments and practices that maintain and reinforce inequities and injustice and potentially threaten the social justice aspirations of the field. Kate argues that those with white privilege have much work to do, unpacking and understanding their privilege if they are to have any chance of playing a role in deconstructing and dismantling the power structures that hold colonizing systems in place. She suggests that for evaluators to be effective allies for Indigenous sovereignty and self-determination, they must undertake ideological, cultural, emotional, and constitutional work. This work will be tough and scary and is not for the faint hearted. But it is vital to unlocking the potential transformation that can come from just and peaceful relationships that affirm and validate Indigenous peoples' ways of knowing and being.
\end{abstract}

Keywords: allies, colonization, evaluation, Indigenous, power, white privilege

Résumé : Le présent article vient la conférence invitée de Kate McKegg, une évaluatrice non autochtone pākehā d'Aotearoa en Nouvelle-Zélande, lors du Congrès annuel de la Société canadienne d'évaluation en 2018. Mme McKegg discute du concept et des conséquences, pour les personnes autochtones, du privilège blanc dans les $\mathrm{Na}$ tions occidentales colonisées. Elle parle des façons par lesquelles le privilège blanc et ses conséquences jouent un rôle dans le domaine de l'évaluation, perpétuant ainsi des pratiques et des sentiments coloniaux qui maintiennent et renforcent des inégalités et des injustices, et menacent potentiellement les aspirations en matière de justice sociale de ce domaine. Mme McKegg fait valoir que les personnes bénéficiant du privilège blanc ont beaucoup de travail à faire pour décortiquer et comprendre leurs privilèges, si elles veulent avoir l’occasion de jouer un rôle dans la déconstruction et le démantèlement des structures de pouvoir qui permettent aux systèmes colonisateurs

Corresponding author: Kate McKegg, 51a Bridle Creek Road, RD 1, Raglan, 3295, New

Zealand; kmckegg@me.com

C 2019 Canadian Journal of Program Evaluation / La Revue canadienne d'évaluation de programme 34.2 (Fall / automne), 357-367 doi: 10.3138/cjpe.67978 
de se maintenir en place. Elle suggère que si les évaluateurs et les évaluatrices veulent être des alliés efficaces pour la souveraineté et l'autodétermination autochtones, ils et elles doivent y aller d'efforts idéologiques, culturels, émotionnels et constitutionnels. Il s'agit d'un travail difficile et déstabilisant qui testera leurs limites. Mais il s'agit aussi d'un travail vital pour permettre la transformation potentielle qui découle de relations justes et paisibles qui affirment et valident les connaissances et l'existence des peuples autochtones.

Mots clé : alliés, colonisation, évaluation, autochtone, pouvoir, privilège blanc

\section{My name is Kate McKegg.}

On my father's side I descend from Irish, Scottish, and English ancestors who arrived in New Zealand on ships in 1840 and 1860-with the families settling in Wanaka, Otaki, and the Manawatu region of New Zealand. On my mother's side I descend from Irish and Scottish ancestors who arrived on ships in the 1860s and 1880s. These early settlers began life on the west coast of the South Island of New Zealand, moving to Napier and then later to Titirangi near Auckland.

My ancestors were weavers, publicans, writers, business people, health professionals, and social activists-handing down strong values about the importance of community and family, of self-reliance, fairness, hard work, and education. They all came to New Zealand for a better life than the one they had-much like the millions of others who migrated from Europe in the nineteenth century. I identify as a Pākehā New Zealander. Pākehā in New Zealand roughly means those who descend from immigrant settlers from the United Kingdom and Europe. What we have in common with each other is the privilege of being beneficiaries of a colonization process in Aotearoa, New Zealand. Our identity as Pākehā settlers has been forged in relation to Māori (the Indigenous people of Aotearoa, New Zealand), developing over time, through the process of colonization (Bell, 2014; Hotere- Barnes, 2015).

I begin with this personal background and history because I believe it's important for those of us who are non-Indigenous, living in colonized lands, to recognize that in all our relationships with Indigenous people in colonized countries, there are power relations that are historical, political, and economic. These relations need to be carefully considered in all the work that we do as evaluators (Berghan et al., 2017). My introduction is intended to locate myself with respect to my ancestors and to the land, as a colonial settler. It models a process of introduction we use at home in New Zealand called mihimihi (a traditional Māori introduction).

As I prepared for the keynote panel presentation at the Canadian Evaluation Society Conference in Calgary in 2018, I pondered the following question asked many years ago by Ernie House: How do we ensure that the evaluation is "socially just as well as true, that it attends to the interests of everyone in society and not solely the privileged" (House \& Howe, 1999, p. 244). I reflected specifically on the hegemonic forces of power and privilege at play for those of us who inhabit 
non-Indigenous, white settler identities (Huygens, 2011) because these forces may well threaten the contribution that evaluation could make to a world of the future that, in the words of Paulo Freire (2000, p. 26), is "less ugly, more beautiful, less discriminatory, more democratic, less dehumanizing, and more humane."

The purpose of my keynote presentation was to present a non-Indigenous perspective on what it might mean to be a non-Indigenous evaluator and an ally in promoting sovereignty and self-determination for Indigenous people.

\section{REFLECTING ON WHITE PRIVILEGE}

I have reflected on Donna Mertens's comments from 2001 that "[d]espite the application of outstanding minds in the evaluation field" from the earliest days of evaluation as we know it, "the social problems that currently confront us globally, and thereby provide on-going justification for the need for evaluation, are quite similar to those that instigated the first calls for evaluation decades ago" (Mertens, 2001, p. 367). We seem to be faced with some of the most pressing and urgent "wicked" problems that humanity has ever faced, such as homelessness, inequality, workforce changes, biodiversity loss, water degradation, and climate change (McKegg, 2013). Along with these global issues, the concerns and voices of Indigenous and minority communities are growing louder about the failure of democratic ideals, such as participation, equity, and social justice (McKegg, 2013).

What role should evaluation and evaluators play in relation to these concerns and voices? For those of us who consider evaluation to be a democratizing practice - with the goal of social betterment-it is a critical time for us to consider our location, role, and stance in relation to the pursuit of key democratic ideals such as equity and social justice. Karen Kirkhart (2015, p. 11) remarked recently on a visit to New Zealand that the evaluation profession values equity and social justice, and that strong evaluation is "evaluation that honours and advances these values in the questions it raises, the evidence it gathers, the relationships it builds, and the privilege it carries." She noted that evaluation and evaluators carry privilege, and that failing to acknowledge the dynamics of power and privilege undercuts evaluation's ability to advance social justice.

The concept of privilege is complicated. There are all kinds of privilege, and they intersect. Often, it is unexamined and invisible to those of us that have it (Kirkhart, 2015). In this paper, I am talking about white privilege. All white people in Western colonized countries have white privilege. Not all are racist, but all benefit from the privilege of whiteness in a system that assumes whiteness is normal. Mostly, whiteness isn't really talked about. White people in Western nations don't even think of themselves as white; they are just people. Everyone else is an "other": a Māori man, or a Black woman, or an Asian child. Whiteness is connected to economic power and class-and is probably least understood by those it privileges (Milne, 2009). A final clarification-when I refer to white settlers, I am referring to those of us who descend from the white settlers of colonized Western nations. 
My interest in talking about white settler privilege stems from frustrationfrustration with the inertia of a dominant socio-cultural, educational, and economic system set up to privilege white settler colonizers (Huygens, 2011) to shift and address deep-rooted, intergenerational injustices that continue to be inflicted on Indigenous people in my own country and other wealthy, colonized nations. In some of the wealthiest nations in the world, such as Canada, New Zealand, Australia, and the United States, Indigenous people are some of the poorest citizens (Cornell, 2006). Cornell (2006, p. 1) argues that "the wealth of these countries has been built substantially on resources taken from these peoples, whose poverty-in the grand scheme of things-is a recent creation."

\section{EVALUATION AND WHITE PRIVILEGE}

The field of evaluation is not immune to having a role in maintaining the dominant system of white privilege and power in Western nations. Evaluation theory and practice is dominated by Western evaluation frameworks that continue to systematically exclude and fail to recognize culturally distinct ontologies and epistemologies (Masters-Awatere \& Nikora, 2017). I see every day the perpetuation of relations of power and white privilege in evaluation. I would argue that attempts and good intentions by the evaluation field to address social justice and equity concerns have largely failed to respond appropriately to these calls for our field to adapt and transform to address the very real needs of Indigenous people for equity, social justice, and sovereignty. The voices of our indigenous colleagues are the evidence I use for this stance (Wehipeihana, 2008; Waapalaneexkweew [Bowman-Farrell], 2018).

Even evaluation approaches that are called participatory, collaborative, and/ or culturally responsive have for too long "been about providing space for nonIndigenous to do evaluation-some more than others. They have in the main been about providing the tips, passwords, and passport for non-Indigenous to do or facilitate evaluation in Indigenous communities and about processes that provide the trappings of permission for non-Indigenous evaluators to work in Indigenous spaces" (Wehipeihana, 2008). Participatory and collaborative evaluation processes, no matter how sensitively they are constructed-when they are controlled and done by white settlers-will not transcend the socio-cultural politics of our historical identities. They do quite the opposite: they perpetuate colonial sentiments (Bishop, 2011). One white New Zealand evaluator and researcher describes believing that these processes will be valid for Indigenous people as "stupid optimism" (Hotere-Barnes, 2015).

I believe that what our field's attempts have consistently failed to recognize and acknowledge, however well intentioned they are, is that they are largely conceived and controlled by non-Indigenous commissioners and evaluators-with Indigenous involvement ranging from token through to infrequent, with occasional genuine partnership. With the power and control of evaluation in the hands of the dominant cultural paradigm, we simply will not be transformative. 
So even when (and perhaps because) there are good intentions to do the right thing, there are no fundamental shifts in power imbalances between Indigenous and non-Indigenous peoples or the systems within which we operate. Unwittingly, our attempts to do the right thing may actually have served to further displace, overshadow, and mask Indigenous evaluation efforts.

It is encouraging to me that we live at a time where Indigenous populations across the world are exploring ways to decolonize, indigenize, and re-imagine knowledge theory and practice in every academic discipline and practice that is informed by their worldviews-including evaluation (Chilisa, 2012). Many colonized and marginalized peoples are working to claim back lost identities, and as evaluator and author Bagele Chilisa says, they are working to create spaces for significant selfhoods as well as writing back and talking back to the West in modes couched in their own histories, cultures, and linguistic and life experiences (Chilisa, 2012).

As privileged white settler evaluators, we are thus presented with an opportunity to challenge ourselves to unpack the invisible knapsack of white privilege (McIntosh, 1988) that often stifles our potential to affirm and validate the knowledge, philosophies, and worldviews of the diverse communities in which we live and work. In the unpacking, we will have to do more than simply point to the ideas; we will have to learn to inhabit them (Meyer, 2011). It is only by inhabiting the deconstruction of white privilege-in a truly holistic way-that we stand a chance of navigating the tricky ground ahead of us (Smith, 2005), of revealing, acknowledging, and dismantling the hidden, unseen, and colossal power that is held firmly in place by those with white privilege.

\section{UNPACKING WHITE PRIVILEGE}

Over some years, my own journey of unpacking my evaluation practice has evolved to encompass an overtly political, values-based orientation that includes affirming Māori sovereignty, as it is set out in Te Tiriti o Waitangi, ${ }^{1}$ as well as an ethical imperative to put Mãori aspirations at the heart of any evaluation that includes, is about, is for, or is done with or as Māori (Wehipeihana, current volume). I have come to recognize that as a Pākehā settler, I am a colonizer and that we still live in a colonizing society. Colonization is not consensual, nor is it over (Margaret, 2018). Institutional racism and culturally unsafe practices are still the normal way to do things (Berghan et al., 2017, p. 20).

My white privilege (and that of all other Pākehā white settlers) comes from the myriad ways in which my Pākehā white settler ancestors benefited from the systems they put in place for their ways-such as language, education, legal systems, and other norms - at the same time denying Māori the basic right to live and express themselves on their lands, in their ways (Margaret, 2018). My privilege is current both because of intergenerational transmission and because colonization is an ongoing activity. The structures of colonization have not been dismantled. 
If there is to be social justice for Indigenous people and communities, in evaluation as well as more generally, the imperative is for those of us who are white, privileged settlers to change.

\section{BECOMING A USEFUL ALLY}

Becoming a useful ally for Indigenous sovereignty and social justice is not a "self-appointed identity" or a badge we acquire, and it's not something we should take on out of self-interest or ego. It is a role that those committed to a collective struggle for social justice take on, for life (Swiftwolfe \& Shaw, n.d.). The work involved is a journey full of complexity and uncertainty. It can be exhilarating and also deeply challenging because our dominant knowledge systems and structures are powerful and resistant to allowing the necessary time and space for equitable co-existence of other knowledges (Wehipeihana \& McKegg, 2018).

The journey of becoming an ally for Indigenous social justice in any context, including evaluation, requires that we shift our gaze from helping others, determining needs for others, designing evaluations for others, to changing ourselves (Huygens, 2011; McKegg, 2013; Smith, 2012). Only when we understand our histories, and our collusion as perpetrators of colonization, and the privilege this affords us, can we then move on to the journey of becoming useful allies. So, as well as supporting the struggles of Indigenous peoples, we must first engage in separate and specific work amongst ourselves (Margaret, 2013, p. 6). The reality is that most of us who identify as white settlers don't know our own histories, let alone those of Indigenous people, nor our place in them. Margaret (2018, p. 3) argues that "we don't know ourselves, our white ways, and we don't know the ways of [the] land. We are poorly equipped to act well in the relationships that allow us to be [on the lands we occupy]."

It's hard to hear the real history; it's not like the one we've been telling ourselves to elevate and justify our positions of privilege. We didn't discover the lands we occupy; the people who were on the lands our ancestors settled didn't benefit from our occupation. We benefited, and continue to do so, at the expense of Indigenous people's cultures, language, economies, and spiritualities.

The following quotation by a New Zealand treaty advocate and educator sums up the practice of working as an ally: "The practice of working as an ally is contextual and relational therefore issues need to be worked through with regard to the specific circumstances and relationship/s. There is not a simple checklist that allows you to 'be a good ally"' (Margaret, 2010, p. 6).

We (those of us who are white settlers and colonizers) must embrace a journey of reconciliation with ourselves. We have to find a way to reconcile our collective cultural cognitive dissonance-between what we've told ourselves and believed wholeheartedly was "the story" of settlement, and what we now know has been the impact of our settlement on Indigenous people. We have to begin with knowing and accepting ourselves, our histories, our privilege and power. Only by 
knowing ourselves can we begin unravelling the intersections between privilege, power, colonization, and racism.

Our readiness to do this work as evaluators is emergent, and we are just beginning the conversations. For Indigenous communities, their experience of evaluation to date has been highly problematic (Blanchet-Cohen, Geoffroy, \& Hoyos, 2018). The use of externally imposed frameworks, criteria, and methods, and the resulting judgments, have had little meaning or value for Indigenous communities; worse, they have perpetuated harmful systems and structures. How we cultivate evaluation practice that is able to respectfully and humbly acknowledge, value, and honour diverse knowledge traditions and paradigms is still, for the most part, an aspiration yet to be realized (Wehipeihana \& McKegg, 2018).

\section{DECOLONIZATION WORK}

If evaluation is, at the very least, to stop doing harm to Indigenous people, we have to begin our own work of conscious decolonization (Berghan et al., 2017; Blanchet-Cohen et al., 2018; Waapalaneexkweew [Bowman-Farrell], 2018). This work is not for the faint-hearted; it involves intentional ideological, cultural, emotional, and constitutional work (Huygens, 2011).

Ideological work involves critically revisiting and then retelling the history of our relationship with Indigenous peoples in order to appreciate that Western, colonial ideologies have shaped all our worldviews and have been self-legitimizing for those of us with white privilege (Huygens, 2011). This ideological work points white settler evaluators toward the need to recognize and acknowledge Indigenous knowledge systems and ways of knowing. And it challenges white settler evaluators to consider the adequacy of our Western theories, frameworks, and knowledge for all evaluation work done for, with, or by Indigenous people (McKegg, 2013; Wehipeihana \& McKegg, 2018).

Cultural work involves critiquing those aspects of our identity, culture, and tradition that will not serve the sovereignty and self-determination of Indigenous people. This implies that we need to rethink and reconsider the roles we play on evaluation projects and teams. Privileging Indigenous voices, values, and traditions is a stance that those of us who are white settlers must be prepared to take if we are to shift the balance of power (McKegg, 2013). This work also points to the kind of relationships we need to learn how to form in our evaluation work, allowing Indigenous people to lead, with us following - where we make time for trust to develop so that we can identify racism and oppressive practice and strategize with each other to take action (Berghan et al., 2017). This is also particularly important work in those spaces that are not considered Indigenous. We can and we must learn to challenge the perpetuation of racism, wherever and whenever we see it.

This is also emotional work. It involves standing up and challenging white privilege, even when it's scary (Swiftwolfe \& Shaw, n.d.). As we bring to the notice of those with white privilege our collective complicity and ignorance, we can expect to have to deal with feelings of shock, fear, guilt, denial, and so on. And when 
this happens, we should not reach for assistance from those we have oppressed. When we ask Indigenous folks to take the time to sit down and educate us on the specific issues that they face and how we can be better allies, rather than doing the work of educating ourselves, we are making it about us. In evaluation situations, our job is to challenge others like us about their power over an evaluation process, design, system, or practice when it has implications for perpetuating inequalities and oppression (McKegg, 2013).

Constitutional work involves the privileged being responsive in practice and form to the aspirations, perspectives, and views of Indigenous people. This means bringing about changes to our policies, procedures, structures, and systems, as well as resource flows. It raises questions for us about how decisions are made throughout evaluation processes. For example, how are the needs and resources for Indigenous evaluation determined? How might we commission and contract for evaluation in ways that shift and disrupt the power and dominant forces that maintain our current practice?

Choosing to embark on this journey will be unsettling, and it is likely that feelings of shame, discomfort, and uncertainty will part of the experience. Working the spaces in between Indigenous and white settlers requires joint commitment to creating conditions where disagreements, emotional flux, and emergence are to be expected and normal (Cram \& Phillips, 2012). Arriving at this recognition takes intellectual, emotional, cultural, and constitutional work over time, which will be challenging (Huygens, 2011). Yet, as Hotere-Barnes (2015) says, to ignore these difficulties perpetuates and preserves racist systems. If we work to shift our thinking and understandings of ourselves and our relationships with Indigenous people, our subsequent actions and interactions are less likely to reinforce negative and unproductive patterns and outcomes (Bishop, 2017). Learning to remain quiet, listen well, pay respectful attention, share power, and sustain relationships over the long term will also unlock powerful learning opportunities and fill your whole self, heart, head, soul, and spirit.

It will also support the unlocking of the innovation potential and the transformation we so desperately need in our thinking if we to reduce the world's suffering that we are all experiencing. The human and environmental suffering that is, in major part, the consequence of colonization surrounds us in rising mental illness and distress; homelessness; workforce, justice, health, and educational inequities; environmental degradation; and more. A catalyst for a sustainable future that is also more just, more equitable, more kind, more holistic can be found if we are prepared to shift our gaze and practice (Hudson, Roberts, Smith, Tiakiwai, \& Hemi, 2012). Jen Margaret (2013, pp. 7-8) so aptly says that "[j]ust and peaceful relationships are critical to the health of communities, and knowledge of how to work as allies has the potential to contribute to positive relationships throughout society."

I have a lifetime commitment to ongoing decolonization work in my personal and professional life in the hope that I can make a contribution to supporting Indigenous people's claims to sovereignty over their lives, including what kind of 
evaluation takes place in all matters that directly or indirectly affect or concern them. I remain hopeful that there will come a time when Indigenous practices, languages, ways of being and knowing, rights, perspectives, and thinking are affirmed and realized, and when this happens, I'm confident it will benefit us all.

\section{NOTE}

1 Te Tiriti o Waitangi is a treaty signed in 1840 by over 500 Mãori chiefs and representatives of the British monarch. It outlined the terms and conditions of settlement for settlers and reaffirmed Māori sovereignty. It is the closest document New Zealand has to a written constitution (Berghan et al., 2017).

\section{REFERENCES}

Bell, A. (2014). Relating Māori and Pākehā: The politics of Indigenous and settler identities. Palmerston North, New Zealand: Massey University.

Berghan, G., Came, H., Coupe, N., Doole, C., Fay, J., McCreanor, T., \& Simpson, T. (2017). Tiriti-based health promotion practice. Auckland, New Zealand: STIR.

Bishop, R. (2011). Freeing ourselves. Transgressions: Cultural Studies and Education, 66. Rotterdam, Netherlands: Sense Publishers.

Bishop, R. (2017). Relationships are fundamental to learning. Principal Connections, 20(3). Retrieved from http://cognitioneducation.com/wp-content/uploads/2017/08/RussellBishop-Editorial-for-CPCO.pdf

Blanchet-Cohen, N., Geoffroy, P., \& Hoyos, L. M. (2018, October). Seeking culturally safe developmental evaluation: Supporting the shift in services for indigenous children. Journal of MultiDisciplinary Evaluation, 14(31), 19-31.

Chilisa, B. (2012). Indigenous research methodologies. Los Angeles, CA: SAGE.

Cornell, S. (2006). Indigenous peoples, poverty and self-determination in Australia, New Zealand, Canada and the United States. JOPNA No. 2006-02. Retrieved from https:// hpaied.org/sites/default/files/publications/Indigenous\%20Peoples,\%20Poverty\%20 and\%20Self\%20Determination\%20in\%20Australia,\%20New\%20Zealand,\%20Canada\%20and\%20the\%20US.pdf

Cram, F., \& Phillips, H. (2012). Claiming interstitial space for multicultural, transdisciplinary research through community-up values. International Journal of Critical Indigenous Studies, 5(2), 36-49. https://doi.org/10.5204/ijcis.v5i2.89

Freire, P. (2000). Pedagogy of the oppressed. New York, NY: Herder \& Herder.

Hotere-Barnes, A. (2015). Generating "non-stupid optimism”: Addressing Pākehā paralysis in Māori educational research. New Zealand Journal of Educational Studies, 50(1), 39-53. https://doi.org/10.1007/s40841-015-0007-y

House, E. R., \& Howe, K. (1999). Values in evaluation and social research. Thousand Oaks, CA: SAGE.

Hudson, M., Roberts, M., Smith, L., Tiakiwai, S.-J., \& Hemi, M. (2012). The art of dialogue with Indigenous communities in the new biotechnology world. New Genetics and Society, 31(1), 11-24. https://doi.org/10.1080/14636778.2011.597979 
Huygens, I. (2011). Developing a decolonisation practice for settler colonisers: A case study from Aotearoa New Zealand. Settler Colonial Studies, 1(2), 53-81. https://doi.org/10. 1080/2201473x.2011.10648812

Kirkhart, K. E. (2015). Unpacking the evaluator's toolbox: Observations on evaluation, privilege, equity and justice. Evaluation Matters-He Hake Tō Te Aromatawai, 1, 7-24. https://doi.org/10.18296/em.0002

Margaret, J. (2010). Working as allies: Winston Churchill fellowship report. Retrieved from http://www.awea.org.nz/sites/awea.org.nz/files/Jen\%20Margaret\%20Winston\%20 Churchill\%20Report\%202010.pdf

Margaret, J. (2013). Working as allies: Supporters of indigenous justice reflect. Auckland, New Zealand: Auckland Workers Educational Association.

Margaret, J. (2018). Ka pū te ruha, ka hao te rangatahi: Change in the Pākehā Nation. State of the Pākehā Nation. Retrieved from https://groundwork.org.nz/resources/

Masters-Awatere, B., \& Nikora, L. W. (2017). Indigenous programmes and evaluation: An excluded worldview. Evaluation Matters-He Take Tō Te Aromatawai, 3, 1-27. https:// doi.org/10.18296/em.0020

McIntosh, P. (1988). White privilege and male privilege: A personal account of coming to see correspondences through work in women's studies. Working Paper No. 189. Wellesley, MA: Wellesley Centers for Women.

McKegg, K. (2013). Evaluation responsibility and leadership in the face of failing democracies. American Journal of Evaluation, 34(4), 579-582. https://doi. org/10.1177/1098214013494458

Mertens, D. M. (2001). Inclusivity and transformation: Evaluation in 2010. American Journal of Evaluation, 22(3), 367-374. https://doi.org/10.1016/S1098-2140(01)00150-3

Meyer, M. (2011). Holographic epistemology: Native common sense. Unpublished Paper.

Milne, A. (2009). Colouring in the white spaces: Cultural identity and learning in school. Auckland, New Zealand: APPA.

Smith, L. T. (2005). On tricky ground, researching the native in the age of uncertainty. In N. Denzin \& Y. S. Lincoln (Eds.), The SAGE handbook of qualitative research (pp. 1-12). Thousand Oaks, CA: SAGE.

Smith, L. T. (2012). Decolonising methodologies (2nd ed.). London, England: Zed Books.

Swiftwolfe, D., \& Shaw, L. (n.d.). Indigenous ally toolkit. Montreal Indigenous Community Network. Retrieved from http://reseaumtlnetwork.com/wp-content/uploads/2018/12/ Ally_web-2.pdf?fbclid=IwAR2Wbpz_SJ781Zg24nJEB0kY3I1s5sCaIx6GnJjwedvcB7vDjnOwie-wrMI

Waapalaneexkweew [N. Bowman-Farrell]. (2018). Looking backward but moving forward: Honoring the sacred and asserting the sovereign in Indigenous evaluation. American Journal of Evaluation, 39(4), 543-568. https://doi.org/10.1177/1098214018790412

Wehipeihana, N. (2008). Indigenous evaluation: A journey beyond participatory and collaborative approaches in evaluation. Presentation at the Australasian Evaluation Society Conference, Perth.

Wehipeihana, N., \& McKegg, K. (2018). Values and culture in evaluative thinking: Insights from Aotearoa New Zealand. New Directions for Evaluation, 18(158), 93-106. https:// doi.org/10.1002/ev.20320 


\section{AUTHOR INFORMATION}

Kate McKegg is an independent evaluation consultant with over 25 years' evaluation experience. She is the director of The Knowledge Institute Ltd (www.knowledgeinstitute.co.nz), co-founder of the Developmental Evaluation Institute (https://developmental-evaluation. org), and a member of the Kinnect Group (www.kinnect.co.nz) and the Tuakana Teina Collective. Kate is a founding member and past convenor of the Aotearoa New Zealand Evaluation Association (www.anzea.org.nz). She is co-editor of New Zealand's only evaluation text, Evaluating Policy and Practice: A New Zealand Reader (2003), and co-editor (along with Michael Quinn Patton and Nan Wehipeihana) of the book Developmental Evaluation: Real World Applications, Adapted Tools, Questions Answered, Emergent Issues, Lessons Learned, and Essential Principles (Guilford Press, 2015). 